absolutely highest temperature, $9^{\circ} \cdot 8$, occurred at 4 p.m. on July 30 under very striking circumstances. For four days previously auroras had been observed in the United States; the magnetic and clectrical conditions showed marked disturbances at Havana; atmosphcric pressure, which had been low, began to rise on the 30 th, on which day, at 2 p.m., the relative humidity fell to 45 , but rose four hours after to 84 . The temperature, which at 4 p.m. was 98.8 , thereafter instantly and rapidly fell, and by 6 p.m liad fallen to $78^{\circ} \cdot 8$. The lowest tempcrature for the year, $55^{\circ} .9$, occurred at $6 \mathrm{am}$. on December 16 , at the termination of a "norther," which overspread the sky with cirri, attended with solar and lunar halos; and was immediately followed by a low barometer, remarkable hygrometric changes and irregularitics in the direction and velocity of the wind.

Excepting a greater tendency to southing during the warmer months, the wind varies little in direction from month to month. The diurnal variation is interesting. From 10 p.m. to 8 a.m. it is E. by S.; at ro a.m. E. by N. ; from Io a.m. to 2 p.m. N.N.E. ; 4 p.m. N.E. ; 6 p.m. E.N.E.; and at 8 p.m. E., thus showing in a marked manner the influence of the sea breeze at Havana. The daily changes in the wind's velocity are very large. The minimum occurs from 4 to 6 a.m., and the maximum from noon to 4 p.m., the maximum velocity being four times greater than the minimum. The strongest winds occur in April, and the weakest in November; the winds in April blowing with double the velocity of those in November. As regards direction, the strongest winds are the sea winds which blow from N.N.E. and E., and the weakest the land-winds from E.S.E., S.E., and S.W., the former blowing with double the force of the latter.

The annual curve of thunderstorms is a very decided one. Of the eighty recorded during 1875 , sixty-five occurred during the five months from May to September, and only three during the four months from January to March and December. The annual rainfall was 42.39 inches, about half of the whole amount falling in August and September, during which time $20 \% \mathrm{I}$ inches fell. Only a quarter of an inch fell in December, and half an inch in November. The total evaporation for the year was about 60 inches, the maximum, $6^{\circ} 92$ inches, being in April, when the air is driest and the winds strongest, and the minimum 3.60 inches in September, October, and November, when the air is most highly saturated and the force of the wind least. As regards the occurrence of rain at different periods of the day, more than 50 per cent. of the whole hours during which rain is noted to have fallen were between noon and 6 p.m., thus closely associating the rainfall with the diurnal period of the thunder storms. The almost total absence of the thunderstorm from the rains of the winter months, as compared with the summer months, when lightning, or some other clectric phenomenon occurs almost daily, is an important feature in the climate of Havana from its bearing on the theory of the thunderstorm.

\section{THE WHALE EXHIBITION IN HAMBURG}

\section{I)}

URING the autumn of last year an exhibition of considerable novelty and interest to zoologists was held in Hamburg, embracing complete skcletons, parts, and cranixe of whales, products of the same, and apparatus used for catching these greatest organisms of the world from the earliest times to the present day.

The suggestion for this exhibition came from the writer of thesc lines, who offered to exhibit three of the greatest fin-whale skelctons in existence. Dr. H. Bolau, director of the Zoological Gardens in Hamburg, succeeded, in spite of many obstacles, in arranging this exhibition and collecting interesting and valuable material, towards which Prof. Pagenstecher, director of the Natu- ral History Museum, also contributed greatly by arranging the cxhibits and obtaining several rare specimens acquired by the German Expedition of I882-83 to South Georgia. In this part were also some splendid watercolour drawings from this island, executed by Herr Mostlaff, which were greatly admired.

The exhibition, which was divided into four parts, viz. one for the whale fauna, one for the hunting-gear, one for the whale products, and one historic-ethnographical, took place partly in the open, partly in a hall.

In the first section, naturally, the Cetacer, were most prominent, these monsters being mounted in the Gardens. Of true Balienida, the Hamburg Zoological Muscum exhibited a cranium of Balcena mysticetus, L., a very fine specimen. Otherwise the Balanopteridæe, or fin-whales, were most numcrous, there being four different species of this family. The most imposing of them all was the skeleton of the "blue" whale (Balanoptera sibbaldii, Gray), the grcatest animal on earth. It measured 75 feet in length, and was mounted in its natural position. The specimen scemed to have been full grown, as no division between the epiphyse and the vertcbral body could be discovered. As an individual osteological curiosity may be mentioned that the jugal bone consisted of two bones, a smaller and a larger piece, which are closely united by strong ligaments.

Not far from this specimen stood the skeleton of the common fine-whale (Balconoptera musculus, Companyo), 63 feet long, which was, as P'rof. Flower describes it, " in adolescent state." The greater part of the thoracic and Jumbal vertebra showed distinct separation between the epiphyses and the vertebral body, which was also the casc with the limbs. Although the length between these two specics is not so very great, there is a marked difference between their structure. The fine-whale is remarkable for its lightness and elegance ; in proportion to its great length, some parts of the skeleton secm indeed quite fragile, whereas the blue whale shows throughout in its structure a massiveness bespeaking enormous muscular powers. The difference became even more striking when the fin-whale was compared with a third species, the Megaptera boops, O. Fabr. This skeleton was 54 feet long, and therefore a large individual, and was found dead at sea between the coasts of Norway and Russia. From the complete development of the ossification and coalescence of epiphyses with the vertebral bodies and respective diaphyses of the extremities it was clearly a full-grown animal. It gives an impression of heaviness, on account of the short, thick bones and the great length of the fore-limbs, I4-I 5 feet, which is very apparent. To this individual belongs the whale-bone complex, part of which was shown. Near the same a cranium of this species of whale was exhibited with a complete whale-bone complex. This was a very finc specimen, and was prepared for the Museum of Natural Sciences at Stuttgart, where it now is.

The above-mentioned skeletons and crania were prepared by me in 1883 at the whaling establishments at Vardö (1at. $70 \frac{1}{2}^{\circ} \mathrm{N}$.), but the three skeletons, which were, I may be permitted to say, very complete and fine specimens, I had stcamed and finished in Hamburg.

In the opon, too, there was mounted a skeleton of Balcenoptera rostrata, Fabr., the smallest of all finwhales; but this specimen left much to be desired in the way of completeness and finish. It was, however, interesting by its history and age, and is perhaps the oldest Cetacea in any museum. For 200 years it has been instated in the town hall at Bremen, where there is an inscription on the wall to the effect that the animal stranded at Bremerhafen on May 9, I669, whence it was brought to Bremen, and the skcleton accorded the abovementioned honour.

As representative of the great "tooth' whales, there was the lower jaw of a spermaceti whale belonging to an 
individual which, in 1849 , was taken at the Canary Islands.

Dr. Bolau had drawn some very interesting maps showing the habitat of the Greenland whale, the Antarctic whale, the blue, and the spermaceti whales, which were greatly admired.

One of the most valuable exhibits was, however, the cranium of a narwhale (Monodon monoceros, L.) with two tusks. It was brought to Hamburg from Greenland in I684. There are, I believe, at present in Europe only a dozen such craniæ, among which the one exhibited here is certainly the oldest. The most remarkable feature about this cranium is, however, if the inscription attached can be relied on, that it is that of a female. The tusk is, as is generally known, never developed in the females. The description is accompanied by a drawing of the whale and a young one, stated to be the offspring of the former. It is, nevertheless, hardly possible to accept this statement, at variance with all experience.

In addition to tusks of narwhals, skeletons and stuffed specimens of other kinds of tooth-whales were exhibited, as, for instance, of Orca gladiator, Delphinus delphis, Phoccena communis, D). tursio, and a cranium of bottlenose Hyperoodon latifrons, Gray, which, according to the latest researches, is only the male of $H$. diodon.

Of the foetus exhibited I may mention those of Balanoptera rostrata, Fabr., Khinodelphis levcoplevrus, Rasch., and one of Megaptera boops, Fabr., only 12 inches long, exhibited by the writer.

Besides the exhibits belonging to the order of Cetaceæ, there were some fine specimens of Sirenia, as Manatus and Halicore, skeletons as well as stuffed animals, exhibited by the University of Kiel. There were, further, a fine collection of seals, of which I shall, however, only mention Otaria Godeffioy, from the coast of Peru. As some of the greatest curiosities, should be added, a perfect stuffed specimen of the sea-elephant, I I feet long, and two sea-leopards from South Georgia.

The exhibition was visited by a considerable number of zoologists, and may, in every respect, be said to have been a success.

The Zootomical Museum, Christiania

\section{CHESTER NEW MUSEUM}

THE foundation-stone of this museum was laid on February 5 by the Duke of Westminster, K.G. We have previously referred to the work done by the Chester Natural Science Society, and the Archæological Society, whose joint museum is now to be placed in a permanent building, uniting under one roof accommodation for it, an art gallery, and every provision for Science and Art Department classes. The remains of ancient Chester, which came to light from time, found their way to the British Museum up to the year I849, when the Rev. W. H. Massie, the Rector of St. Mary's-on-the-Hill, called a meeting to consider the formation of a museum, and a society was formed for "the illustration and preservation of the remains of antiquity and other objects of interest in the city and in the county." The Society's "collection" was first housed in a cupboard at the Commercial Buildings; thence it was removed, first, to the Episcopal Palace in Abbey Square, afterwards to a house in Lower Bridge Road, to join the Museum of the Natural Science Society, whose collections are of considerable extent and essentially local in character, thanks to the marked love of nature and zeal for scientific research infused into many of the Chester citizens by the founder of the Society, the late Canon Kingsley, and the admirable rules for directing local investigation by which the Society is governed. Under the presidency of Prof. McKenny Hughes, the Society remains as vigorous as ever, as is the Archæological Society under that of Dean Howson, who, since the failing health of $\mathrm{Mr}$. Thomas Hughes, F.S.A., to whom great credit is due, has taken an active interest in the Society, and in 1882 became the chairman of a joint committee to secure a building to answer all the requirements of science and art in Chester. This Committee selected a site in the Grosvenor Road, the greater part of which was at once placed at their disposal by the Duke of Westminster, who, moreover, headed the subscription list with the munificent sum of 4000 ., to which the Committee have since received promises of sums amounting to a further 3500 .

The architect is Mr. Thos. M. Lockwood, of Chester; the tender for the erection of the work accepted by the Committee is for $8150 /$. The elevation of the building, with its octagonal turret, with lantern surmounted by a quaint ogee roof, surmounting a steep-pitched roof, suggests the municipal architecture of Holland. The joint library and reading room is $2 \mathrm{I}$ feet by 19 ; the natura history museum is 36 feet by 25 ; the lecture theatre $44 \frac{1}{2}$ feet by 30 ; the art and archæological gallery is 60 feet by 23 ; on the first floor are science class rooms; on the second those for art. Space is reserved for future extensions in all departments.

Prof. McKenny Hughes stated the object of the Museum to be three-fold, being "intended for teaching, for study, and for exhibition. We have long carried on teaching in this old city in connection with the societies which have for their object the study of natural science, but that is to be extended. We have already extended it by putting ourselves in connection with the teaching powers of South Kensington, and now we will bring this into shape and have class-rooms and teachers definitely appointed to carry on the work which has been so nobly taken up by your citizens. The Duke has mentioned already that he felt that a great deal of the work had been done by the enterprise of the citizens. Well, that is the work which we intend to carry on in the teaching departments of this institution; but it is also intended for study. The world is going on fast in the direction of knowledge. Every one is trying to acquire knowledge which shall be turned to money, or which shall be pursued for its own sake, or which will add to the comfort of the community. In all these directions we hope to assist. Men may come in here and study in the library, or in the laboratories, or in the museum."

At the subsequent dinner the chairman, the Dean of Chester, stated that Canon Kingsley gave impulse to the study of natural history in this place, which has by no means lost its momentum. What the Duke of Westminster has said concerning the deep interest taken today in scientific subjects is most strictly in harmony with the facts of the case. There is here, deeply-rooted in the minds of many, a determined love for science of this kind, which is the best possible augury for benefits to result from our muscum.

Sir Philip Cunliffe Owen, K.C.M.G., C.B., responding for art, said, "this is a museum aftcr my own heart, for I think it corresponds entirely with what was in the mipd of the Princc Consort when he established the Science and Art Department and the South Kensington Museum. It was a part and parcel of his scheme that the teaching and the examples should be under one roof, and it has been found that the example of the Science and Art Department, combined as it is with one of the finest art museums in the world, and combinecl as it will be, I hope, in the near future with one of the fincst science museums that may be created, has done more good, not only in this country, but throughout the world, than anything else which had been thought of before. When we think of the museums of the past, we know that they could not speak for themselves; they were examples, but however interesting and however ancient they might have been, they had no speaking powers, because they were not in combination with a teaching organisation."

CHAS: E. DE RANCE 